\title{
Entrepreneurial Engagement Choice and Credit Constraints: Empirical Analysis of Urban Informal Microentrepreneurship in Sri Lanka
}

\author{
Damayanthi B.W.R. ${ }^{1} \&$ Gamini Premarathne ${ }^{2}$ \\ ${ }^{1}$ University of Sri Jayewardenepura, Nugegoda, Sri Lanka \\ ${ }^{2}$ Universiti Brunei Darussalam, Brunei Darussalam \\ Correspondence: Damayanthi B.W.R, Department of Economics, Faculty of Humanities and Social Sciences, \\ University of Sri Jayewardenepura, Gangodawila, Nugegoda, Sri Lanka. Tel: 94-280-2014. E-mail: \\ bwrdam@sjp.ac.lk
}

Received: July 4, 2015 Accepted: July 29, 2015 Online Published: August 28, 2015

doi:10.5539/ass.v11n26p30 URL: http://dx.doi.org/10.5539/ass.v11n26p30

\begin{abstract}
Microenterprise approach is increasingly acknowledged and policy based approach that recognizes micro entrepreneurs as the core of the informal sector, which needs to be assisted to start at entrepreneur level or to become growing, self-sustaining businesses to signify its contribution to economic growth and development in the global south. This study investigated the existence, effects of credit constraints and the determinants of entrepreneurial engagement choice taking a sample of 300 micro entrepreneurs who reside in underserved settlements in Sri Lanka. Accordingly, whether the entry choice is constrained by the availability of credit is empirically examined in a multivariate setting, applying discrete choice model on the conceptual basis of the theory of occupational choice. It was found a positive correlation between wealth and the probability of starting a business which implies that initial wealth determines the amount of capital required for business startups thus providing evidence of financial constraints. Initial wealth, education, tradition, trained or parent's occupation and previous employment reported as important predictors on the probability of starting a business as a self employed or entrepreneur compared to subsistence activities. This study provides useful insights for policy makers to plan their activities to promote entrepreneurship in the urban informal sector in the country rather than formulating ad-hoc policies to provide fixed financial assistances on mis specified targets.
\end{abstract}

Keywords: micro entrepreneurs, financial constraints, wealth, multinomial logit model, urban informal sector, Sri Lanka

\section{Introduction}

The microenterprise approach is often justified and increasingly being acknowledged as the most viable path to achieve economy's growth through generation of income, wealth and employment, reduction of poverty, (Daniels, 1999; FIELD, 2012); provision of the seedbed of industrialization (Grosh \& Somolekae, 1996) and generally promoting social, economic and human development in developing as well as developed world (Mullei, 2002; Levy \& Bradburd, 1995; World Bank [WB], 2013). Therefore, the microenterprise approach to the informal sector has been identified as a policy based approach that recognizes micro entrepreneurs as the major part of the informal sector (Gunatilaka, 2008). It is stressed that they should be dynamic, growing and self-sustaining businesses to signify their contribution to foster economic growth, generate productive additional employment, and reduce deprivation (Gunatilaka, 2008; Mead \& Liedholm, 1998; Pisani \& Patrick, 2002; WB, 2013).

In brief, microenterprise graduation is the key to this accepted or suggested development path in moving the economy ahead (WB, 2002; Levy, 1991; Daneals, 1999). But the stylized fact, in low income countries is the presence of a large number of micro enterprises with subsistence activities which rarely make the transition to the formal sector as entrepreneurs (Gollin, 2008, Woodruff, 2012). The reasons behind this nature may be attributed to their activity selection, entry choice, future vision, objectives of starting the business, resource availability, including adequate financial access, educational level, skills acquired, poverty level and so on (Cunningham \& Maloney, 2001; Daniels, 1999; Kuzwila, 2005; Mead \& Liedholm, 1998; Roy \& Wheeler, 2006; Shaw, 2004). Careful investigation of these factors shows that most of these impediments should be corrected at the starting stage and it can be done providing correct assistance for the entry-stage choice. 
As it is reported in the global literature the most widely documented facts that constraint informal entrepreneurship in the developing countries are skills and initial capital requirements (Cunningham \& Maloney, 2001; Desai, 2010; Fields, 1990; Naudé, 2010). In this respect, there is a vast literature that examines the transition into self employment and credit constraints (Evans \& Jovanovic, 1989; Evans \& Leighton, 1989; Magri, 2011; Mondragon-Velez, 2010). However, the most crucial fact whether credit matters in determining the entry-stage and the determinants of entrepreneurial entry have not been in consideration so far.

Informal microenterprises are ubiquitous in the urban sector serving as the major source of employment in Sri Lanka (Arunatilake \& Jayawardena, 2005; Ebert, 1999; Gunathilake, 2008; Hettige, 1989; Nanayakara, 2006). It is estimated that more than 45 percent of the urban poor in the country depends on microenterprise activities (RUSP [Relocation of Underserved Settlements Project], 2009). Some anecdotal evidences reveal a lack of access to credit as a major impediment for microenterprise activities in the urban informal sector in the country (Sevanatha, n. d.) while some studies done on micro entrepreneurship claimed credit access and skill would be significant complementary factors that constraint the graduation of micro enterprises (De mal et al, 2008; Fairoz, Hirobumi, \& Tanaka, 2010; Sumanasena, 2005). However, none of the studies have investigated the impact of financial constraints and the factors that determine the micro enterprise entry-stage choice.

Quantification of the credit effect and the other factors that determine entry-stage or engagement choice is crucial for correct policy signals in order to channel scarce resources to the correct targets and thereby achieve prospected economic growth in a developing country like Sri Lanka. Therefore, this study aims to explore the existence and the impacts of financial constraints and other related factors on entrepreneurial engagement choice in the urban informal sector in Sri Lanka. It was found that the micro entrepreneurs are credit constrained in their entrepreneurial entry choice. Specifically, this study makes its novel contribution by addressing the following research questions;

(1) Are micro entrepreneurs credit constrained in their entry-stage choice?

(2) To what extent does the financial constraint matter at entrepreneurial entry?

(3) What are the other significant contributors of entrepreneurial entry?

\section{Literature Review}

The degree of accessibility of capital markets or the role of credit in becoming entrepreneurs differs amongst the economic theorists. From the classical and even the old neo classicist's point of view, there is no issue or constraints on credit where the capital market is assumed to be perfect. According to them capital market is imperfect. Entrepreneurs only for those who have a certain level of reputation can borrow from this market due to asymmetric information. Alfred Marshal assumes that the capital market is perfect to borrow, but the entrepreneur working on borrowed capital has a disadvantage in the operation of his venture: he needs to bear an additional cost for the banker in order to compensate for his 'personal' risk. Therefore, Marshal stressed the need of having some sort of wealth is very advantageous to become an entrepreneur. Schumpeter works on the assumption of the perfect working of capital markets. However, "innovations can be equally well supported by own wealth as by credits. If they are supported by own wealth, the entrepreneur fulfills two jobs: the entrepreneur's job and the banker's job" (Schumpeter, 1949 as in Praag, 1999). The capital market viewed in the Knight's economy is imperfect. According to him, entrepreneurs need wealth; at least enough to pay production factors their guaranteed remuneration. However, Knight (1971) acknowledges the possibility of the entrepreneur being able to convince a banker of the accuracy of his judgments in order to borrow the capital required. Kirzner, an Austrian thought, agrees with Schumpeter in this respect. Entrepreneurship is not restricted to persons who own resources themselves. 'But it is still correct to insist that the entrepreneur qua entrepreneur requires no investment of any kind' (Kirzner, 1973, p. 49). Funds are supplied by capitalists as long as the entrepreneur is in a position to finance the necessary interest payments. Synthesizing these main theories of entrepreneurship with testable hypotheses, Praag (1999) implied that one of the possible impediments to entrepreneurship is lack of capital or liquidity constraints and there by an ownership of initial capital or wealth is advantageous on entry and the success of entrepreneurship where there is imperfect capital market.

Accordingly, one of the ways to identify financial constraints is to look at the importance of household wealth in the decision to become an entrepreneur. In the absence of correlation between wealth and entrepreneurial talent, wealth should matter in this decision only for financially constrained households (Evans and Jevonic (1989). Because provided that they have the ability to obtain capital as the price takers in capital market, the decision to start a new venture should not depend on the prospective entrepreneurs' personal wealth endowment. Following this, many prior academic studies have focused on the importance of liquidity constraints to entrepreneurs through wealth. However, they yield contradictory results and still in debate. 
Numerous studies have found a positive relationship between wealth and entering entrepreneurship, and interpret this as evidence of the existence of liquidity constraints following Evans and Jevonic (1989). Evans and Leighton (1989) first found that the probability of entrepreneurial entry is roughly independent of age and labor market experiences. They used the data from the National Longitudinal Survey of Young Men for the period from 1966 to 1981 and the Current Population Survey for the period from 1968 to 1987. Further, they presume that potential entrepreneurs are liquidity constrained because the size of net worth was reported to be positively correlated with the odds of being an entrepreneur. In their study, Evans and Jovanovic (1989) revisited Evans and Leighton (1989) work and interpret the positive relationship between wealth and starting a business as evidence of the existence of liquidity constraints by using the self employment concept. They analyzed the effects of family net assets on the probability of becoming self employed and found the evidence that liquidity constraints bind.

Mondragon-Velez (2010) estimated a life cycle model of occupational choice, including human capital heterogeneity and found wealth as a key element of the occupational decision at the individual level in the USA. This finding is also supported by Lazear (2002). Further, in a different angle, Cressy (2000) extends the Evans and Jovanovic (1989) model to include uncertainty and risk, and finds that decreasing absolute risk aversion can explain the positive relationship between wealth and entrepreneurship. Magri (2011) provided the evidence on household wealth matters in the decision to become an entrepreneur in Italy.

A key requirement to study the relationship between wealth and entrepreneurship is a measure of wealth that is not endogenous to the entrepreneurial decision. The norm comes because the wealth from the prior period could be artificially high since the household has been saving specifically to fund a new business enterprise. Therefore, a various forms of wealth proxies have been tested in the literature. In this respect Evans and Leighton (1989), Gentry and Hubbard (2001), and Lel and Udell (2002), Quadrini (1999) had shown that wealth or proxies matter in the entrepreneurial decision showing a positive relationship between wealth and entrepreneurship transition vice versa. Combining family assets with the inherent as wealth Holtz-Eakin, Joulfaian, and Rosen (1994a, 1994b) advance that wealth significantly positively impacts on the probability of entrepreneurial choice. Moreover, they propose that liquidity constraints significantly affect entrepreneurial failure as well.

Blanchflower and Oswald (1998) use the recent receipt of an inheritance as a way to deal with the potential endogeneity of wealth. The rationale is that if potential entrepreneurs face liquidity constraints (or owing a substantial capital stock is significant in enterprise entry), then the receipt of an inheritance should loosen the constraint and have a positive effect on the propensity to start a business. The findings showed that such receipts are not only statistically significant but also quantitatively important supporting monotonic relation of wealth and entrepreneurship. Lindh and Ohlsson (1996) support this suggesting that Swedish individuals who have received an inheritance or won the lottery are more likely to be self-employed.

Despite many studies have interpreted the positive relationship between wealth and entrepreneurship as evidence of liquidity constraints, some studies have questioned this claim. Hurst and Lusardi (2004), for example, examined the relationship of household wealth and entrepreneurial entry using business ownership in the Panel Study of Income Dynamics from 1984 to 1994 and found no relationship between wealth and entrepreneurial entry for most of wealth distributions. According to them the positive relation existed only for households in the top 5 percent of the wealth distribution. Further, they argue that for the majority of households starting a business, the capital requirements are of such a size that liquidity constraints are not binding.

It is shown that the role of liquidity constraints on entrepreneurship has presented a persistent puzzle for scholars. It is possible that these contradictory results may be related to the relative importance of different types of financing. Entrepreneurs need startup capital to invest in their projects as well as operating capital to finance everyday expenses. Presumably, individuals with very high levels of wealth should have enough finances to cover both these capital needs.

Besides liquidity constraints, a considerable portion of the literature revealed the impact of other covariates such as family background, parental wealth or inherited experience on the propensity to be self-employed and the probability of self-employment entry. It is sometimes not easy to extricate the impact of liquidity constraint matters of family environment and is certain that individuals who are coming from entrepreneurial families are likely to fall in to the same field than their counterparts. In many instances these people benefit from parental wealth, intergenerational links and business experience, hence face less financial constraint on setting up their own businesses (Burke, FitzRoy, \& Nolan, 2000; Dunn \& Holtz-Eakin, 2000). Davidsson and Honig (2003) support this idea. They found that formal education, previous work experience, having entrepreneur parents as well as social and family ties as robust predictors of entrepreneurial entry probability. 
From the demographic point of view, the individual's occupational choice towards entrepreneurship is basically determined by his or her basic physical characteristics (Bonte, Falck, \& Heblich, 2009), productivity, and the stock of human capital and thereby age. Once the age is taken, ability to store and process information, solve problems, deal with complexity, adjust to new situations, and develop strong social ties and business networks (called tacit knowledge) (Kaufman \& Horn, 1996; Ryan et al., 2000); change risk aversion, time discounting over the life cycle and hence there is a golden age of entrepreneurship in human lifespan (Bonte, Falck, \& Heblich, 2009). However the effect size, type of functional form and the effectiveness of the significance varies highly (Blanchflower \& Meyer, 1994; Blanchflower, 2000; Evans \& Leighton, 1989; Delmar \& Davidsson, 2000; Mueller, 2006) while some studies find it is insignificant (Evans \& Jovanovic, 1989). When gender impact is considered in terms of entry choice, it was found that men are more likely involved in entrepreneurial activity than women in developed country setting (Minniti, Arenius, \& Langowitz, 2005; Reynolds et al., 2002) while women are prominent in developing countries (Daniels, 1999; De Mel \& Woodruff, 2010; Mead \& Liedholm, 1998).

Almost all of the above studies have been conducted in the developed countries and the dependent variable is binary in nature representing the transition into entrepreneurship. Therefore, this study makes its contribution analyzing a sample from a developing country and more specifically the urban informal sector (urban underserved settlements), which has not been in consideration so far. Further the conventional binary response variable extended into polychotomous advancing the research in order to represent the high heterogeneity within the urban underserved sector in terms of entrepreneurial entry and to address the contemporary need of examining covariates of entrepreneurship rather than mere subsistence activities.

\section{Theoretical Framework}

The theoretical model that used in this study is from Evans and Jovanovic (1989). Considering the works done by Lucas (1978) and Jovanovic (1982), they postulate that there is a positive relationship between the probability of becoming self-employed and the wealth of the entrepreneur due to financial constraints provided that there is no correlation between skills and wealth. Accordingly, agents in the economy differ from their initial wealth endowment (w) and their ability level (\$). Knowing the skill level and the capacity to invest, the occupational choice of the agents depends on the comparative advantage that they gain from running a firm in an unconstrained market. However, with market imperfections and especially with capital constraints the optimal gain depends on the cost of capital. Since the potential capital borrowing is limited by initial wealth endowments, the occupational choice eventually depends on access to capital and thereby wealth. If a household chooses to operate at subsistence activity, it requires no rental capital. And the skill is irrelevant because they use no technology. When market interest rate is $r$, their expected net income (y) is,

$$
\mathrm{y}^{\mathrm{s}}(\mathrm{w})=\delta+\mathrm{rw}
$$

where rw is the return on the household wealth $(\mathrm{w})$ and $\delta$ is a productivity parameter. This rate of change in productivity $(\delta)$ is assumed constant along the subsistence sector.

But if the household use technology and pay capital rentals as an entrepreneur (with skill $\phi$ uses $\mathrm{k}$ amount of capital) the output (Y) is given by,

$$
\mathrm{Y}=\phi \mathrm{k}^{\alpha} \varepsilon
$$

Where $\alpha \in(0,1)$ is the elasticity of output with respect to capital and the term $\varepsilon$ is $\log$ normal disturbance reflecting a productivity shock, independent from $\phi$ and $\mathrm{w}$, with positive support, mean 1 and variance $\sigma^{2}$. At the end of the period household will earn a net income of,

$$
\mathrm{y}=\phi \mathrm{k}^{\alpha} \varepsilon+\mathrm{r}(\mathrm{w}-\mathrm{k})
$$

If $\mathrm{w}<\mathrm{k}$, the entrepreneur is a net borrower and $\mathrm{r}(\mathrm{w}-\mathrm{k})$ is the amount that he should pay at the end of the period. A households can borrow only up to an amount which is some fixed proportion of their initial wealth, $(\eta-1) \mathrm{w}$, but cannot exceeds it. The most that can be invested in their entrepreneurial business is then equal to $\eta w$, where the parameter $\eta$ satisfies $\eta \geq 1$ and assumed to be equal for everyone.

If the interest rate, $r$, is equal for everyone and further for simplicity the lending rate and the borrowing rate is assumed to be equal, the entrepreneur's optimal investment capital then solves for his expected profit maximization problem

$$
\max \left\{\phi k^{\alpha}+r(w-k)\right\} \quad \text { s.t. } 0 \leq k \leq \eta w
$$


at an interior maximum that leads to solution,

$$
k^{*}=(\phi \alpha)^{1 /(1-\alpha)} r^{-1 / 1-\alpha}
$$

As long as the entrepreneur is unconstrained this will be the feasible solution. It implies that

$$
\eta w>\left(\frac{\phi \alpha}{r}\right)^{1 /(1-\alpha)}
$$

An entrepreneur will be unconstrained if his ability $\phi$ satisfy

$$
\phi \leq r \propto^{-1}(\eta w)^{(1 / 1-\alpha)} \equiv \bar{\phi}
$$

Similarly, the unconstrained condition implies that his initial wealth w must satisfy

$$
w \geq \eta^{-1}\left(\phi \propto r^{-1}\right)^{1 /(1-\alpha)} \equiv \bar{w}
$$

Entrepreneurs will be unconstrained only if their ability is low enough for a given level of wealth as shown by the Equation 5.5. This indicates that holding household wealth constant, borrowing constraints are more likely to bind for higher skilled households. And as implied by Equation 6, for a given level of ability, entrepreneurs are unconstrained only if their initial wealth is high enough. Therefore the actual financial constrained entrepreneurs are those with initial wealth below the critical threshold $\bar{w}$ or with ability higher than $\bar{\phi}$. For these households, the maximization constraint will be binding so that they will invest $\eta w$ in their entrepreneurial business, even though they would like to invest more.

Entrepreneurs' expected net entrepreneurial income therefore takes the following form.

$$
y^{E, S E}(w, \phi)=\left\{\begin{array}{cc}
(1-\alpha)\left(\frac{\phi \alpha}{r}\right)^{1 /(1-\alpha)}+r w & \text { if } w \geq \bar{w} \\
\phi(\eta w)^{\alpha}+(1-\eta) r w & \text { otherwise }
\end{array}\right.
$$

This clearly implies that household chooses entrepreneurship only if their expected profit from doing so exceeds what they would get by staying in the subsistence. In other words, they become entrepreneur only if their comparative net earnings, $y(w, \phi)=y^{E}(w, \phi)-y^{S}(w)$ or $y(w, \phi)=y^{S}(w, \phi)-y^{S E}(w)$ is positive. However when comparative gain function is derived as,

$$
y(w, \phi)=\left\{\begin{array}{cc}
(1-\alpha)\left(\frac{\phi \alpha^{\alpha}}{r^{\alpha}}\right)^{1 /(1-\alpha)}-\delta & \text { if } w \geq \bar{w} \\
w\left(\phi \eta^{\alpha} w^{\alpha-1}-\eta r\right)-\mu & \text { otherwise }
\end{array}\right.
$$

It $y(w, \phi)$ does not depend on the initial wealth $\mathrm{w}$ when wealth endowment is higher than the critical wealth threshold $(\bar{w})$. This implies that the decision on starting stage the business for wealthier households is an invariant of their capacity to get funding but their skill. On other hand it implies that having high skills is not enough to become an entrepreneur whereas a minimum level of initial wealth is also required for this purpose. On the assumption of that there is no correlation between initial wealth and skill level the probability of entry choice is correlated with initial wealth only when there are credit constraints. In order to examine whether urban informal micro entrepreneurs are credit constrained at their entrepreneurial entry choice this preposition has been explored utilizing the multinomial logistic model.

\section{Research Methodology}

\subsection{Sample Design and Data Collection}

Data were taken from a multi stage cluster sample of 300 micro entrepreneurs who reside in urban underserved settlements in Colombo. From 48 administrative wards of the Colombo Municipal Council (CMC) the most Underserved Settlements [USS] concentrated 6 wards were selected at first. From the selected wards seven geographical clusters were selected and then a total of 12 enumeration areas were selected representing each cluster. Finally a random sample of micro entrepreneurs was considered. Registered list of micro entrepreneurs is not available for the informal sector as usual in many other countries. Therefore, in the selected localities, randomly chosen business places were approached and the questionnaire was administered. However the survey 
team was advised and properly guided to minimize bias within the enumeration area and keep diversity of selecting observations. The main survey tool for the study was a questionnaire which consisted close ended questions. Self administered method was used for a part of the field survey whilst interview method played the major role. Consistency was checked for two methods before inputting into the data analysis. Data cleaning, validation and the models were estimated using the facilities available in SPSS 16.0.

\subsection{Empirical Model for Entrepreneurial Entry Choice}

The empirical approach stemming from the above conceptual model is a discrete choice based on random utility theory. Since the outcome variable is defined as unordered and with multiple choices, Multinomial Logistic model (MNL) which specified below is estimated for the odds of wealth across entrepreneurial choices. If $j$ indicates the category a microenterprise owner falls into. In this framework, it is allowed the categories in a choice set to take on three values $(j=0,1,2)$ for subsistence, self employed and entrepreneur in entrepreneurship engagement levels respectively.

Considering the choice set of the current study with three elements $(0,1,2)$ : choice of starting subsistence activity (0), self employed (1) or entrepreneur (2), the random utility model can be written as,

$$
\begin{gathered}
\text { Subsistance : } U_{0}=x \beta_{0}+\varepsilon_{0} \\
\text { Self employed: } U_{1}=x \beta_{1}+\varepsilon_{1} \\
\text { Entrepreneur : } U_{2}=x \beta_{2}+\varepsilon_{2}
\end{gathered}
$$

As it is assumed that $\varepsilon_{0}, \varepsilon_{1}, \varepsilon_{2}$ are independent and follow Gumbel distribution. Then the probability that a person choosing alternative $i$ rests on the probability that the utility of alternative $i$ exceeds the utility of all the other choices, the probability that an individual choose to start each activity can be demonstrated as,

$$
\begin{gathered}
P_{0}=P\left(U_{0}>U_{1}, U_{0}>U_{2}\right)=\frac{e^{x_{\beta_{0}}}}{1+e^{x \beta_{0}}+e^{x \beta_{1}}} \\
P_{1}=P\left(U_{1}>U_{0}, U_{1}>U_{2}\right)=\frac{e^{x \beta_{1}}}{1+e^{x \beta_{0}}+e^{x \beta_{1}}} \\
P_{2}=P\left(U_{2}>U_{0}, U_{2}>U_{1}\right)=\frac{e^{x \beta_{2}}}{e^{x \beta_{0}}+e^{x \beta_{1}}+\mathrm{e}^{x \beta_{2}}}
\end{gathered}
$$

As it stands, the cumulative logistic distribution function in a non-linear form, the model's parameters are identified in logits which gives very technical interpretation of the coefficients. Thus, it could be changed by some linear transformation and an identical set of estimated probabilities would result. The standard normalization employed for the purpose of interpretation in the literature is to make "baseline" category against other alternatives which are accessed via log odds ratio. By keeping the choice zero as the base,

Accordingly

$$
\frac{P_{i j}}{P_{i 0}}=\frac{e^{x_{i} \beta_{j}}}{e^{0}}=e^{x_{i} \beta_{j}}
$$

$$
\ln \left(\frac{P_{i j}}{P_{i 0}}\right)=x_{i} \beta_{j}
$$

Where in the general form,

$$
\ln \left(\frac{P\left(y_{i}=j\right)}{P\left(y_{i}=0\right)}\right)=\sum_{i=1}^{n} \beta_{i j} x_{i j} \quad \forall \quad j=1,2 \quad j \neq 0
$$

Taking the logarithm of the ratio of any two choice probabilities to get the log odds ratio, the full model for the wealth effect on entrepreneurial entry choice when controlling for personal and household characteristics, was specified as follows.

$$
\ln \frac{P_{i j}}{P_{i k}}=\beta_{0}+\beta_{1} \text { wealth }+\beta_{2} \text { education } \quad+\beta_{3} \text { tradition }+\beta_{4} \text { risk }+\beta_{5} \text { inher }+\beta_{6} d_{\text {prjo }}+\beta_{7} d_{g e n}+\varepsilon
$$

In this multinomial setting, the dependent variable is the log odds ratio of three entrepreneurial entry choices: Subsistence, Self-employed and Entrepreneur which take values 0,1 and 2 respectively. Independent variables 
included were personal and household characteristics: level of education, whether they choose the activity because of the tradition; risk taker; whether they had inherent; whether they have previously employed and the gender of the micro entrepreneur. Wealth that used in the model is the value of capital related assets prior to the entrepreneurial decision, therefore unlike the most of measures used in the literature, not to be endogenous. In other words, wealth used in the study is not the values from the survey year, but what they used as the starting capital at the beginning of the business. Therefore, it is unaffected by any gains in wealth due to the business. Despite the main wealth measure, a wealth proxy was created for sensitivity analysis. In constructing a suitable ex-ante total wealth proxy, this study used an asset index approach which is increasingly advocated by the scholars (Moser \& Felton, 2007). The values of this aggregate index are created utilizing principal component analysis over 14 consumer durables from the household belongings and basic infrastructure facilities which were acquired prior to the beginning of the microenterprise. Therefore the problem of endogeneity was controlled from the wealth proxy.

\section{Results}

Table 1 presents the results from the multinomial logit model, where the dependent variable takes 0,1 , and 2 for subsistence, self-employed and entrepreneur respectively. The first three columns reports, odds of choosing self-employed rather than subsistence while the second three columns reports, the choice probability of being in entrepreneur against subsistence. As pointed out in Table 1, wealth is positively significant for all three choices of entrepreneurship at the $5 \%$ level of significance, $\chi^{2}(1)=1.2, p<.05$ and $\chi^{2}(1)=1.6, p<.05$ for self-employed and entrepreneur choice respectively. Level of education is positively significant with at the $10 \%$ level for self-employed while it is significant at the $5 \%$ for entrepreneur choice compared to subsistence activity. Non-risk taker significantly negatively associated with choosing entrepreneur activity whilst it has no predictive power over self-employed. Being female is inversely significant with entrepreneur choice, $\chi^{2}(1)=.267, p<.001$. However, this variable is not significant for choosing self-employed. Being a person whose parents are self-employed or having a training has a significant positive effect, $\chi^{2}(1)=1.8, p<.05$ on entering as entrepreneur while it cannot predict entrepreneurial choice probability of the self-employment group. Unemployed are more likely to start as self-employed whilst this factor is positively significant at conventional levels for all three choices. The results of the multivariate models estimated for non-linear specification of wealth and the wealth proxy are reported in Tables 2 and 3 respectively. Accordingly, all wealth and education design variables are significantly associated with entrepreneurial engagement choice at conventional levels. Compared to low educated group secondary educators are significantly, but negatively related to the odds of choosing to be self-employed, $\chi^{2}(1)=1.4, \mathrm{p}<.05$.

\section{Discussion}

Table 1. Choice probability of entrepreneurial engagement: Multinomial logit estimates

\begin{tabular}{|c|c|c|c|c|c|c|}
\hline \multirow{2}{*}{ Variables } & \multicolumn{3}{|c|}{ Self Employed } & \multicolumn{3}{|c|}{ Entrepreneur } \\
\hline & B & Wald & Odds R & B & Wald & Odds R \\
\hline \multirow[t]{2}{*}{ Intercept } & -0.739 & 3.973 & & -2.114 & 20.046 & \\
\hline & $(0.371)$ & & & $(0.472)$ & & \\
\hline \multirow[t]{2}{*}{ Gender(F) } & -0.632 & 3.573 & 0.531 & $-1.319^{* * *}$ & 7.652 & 0.267 \\
\hline & $(0.334)$ & & & $(0.477)$ & & \\
\hline \multirow[t]{2}{*}{ Education level } & $0.261^{*}$ & 1.983 & 1.298 & $0.671 * *$ & 10.354 & 1.957 \\
\hline & $(0.185)$ & & & $(0.209)$ & & \\
\hline \multirow[t]{2}{*}{ Non risk taker } & -0.205 & 1.063 & 0.814 & $-0.386^{* *}$ & 1.701 & 0.994 \\
\hline & $(0.199)$ & & & $(0.235)$ & & \\
\hline \multirow[t]{2}{*}{ Inherent } & 0.015 & 0.002 & 1.015 & 0.274 & 0.522 & 1.315 \\
\hline & $(0.314)$ & & & $(0.378)$ & & \\
\hline Unemployed & $0.639 * *$ & 4.529 & 1.895 & $0.082^{*}$ & 1.488 & 1.326 \\
\hline
\end{tabular}




\section{(0.300)}

Parents occu/Tradition

0.018

Initial wealth

$0.215 * *$

1.879

1.239
$(0.065)$

$0.612 * *$

3.300

1.845

(0.337)

$0.462 * * \quad 6.087$

1.587

$* * * \mathrm{p}<0.001 ; * * \mathrm{p}<0.01 ; * \mathrm{p}<0.05,(\mathrm{SE})$

Multivariate analysis showed that the coefficient of wealth covariate is positive and significant, however the effect is not very large compared to some other variables in the model. A unit increase in wealth leads only a little less than one-half percentage point increase in the probability of starting a business at the self-employed level. A similar result is found in the entrepreneurship level with the marginal effect but stronger than self-employed. Though the common sited issue for the micro entrepreneurs is the credit constraint, wealth doesn't seem to be the most prominent factor behind entrepreneurial choice when all the variables considered. However, it is the most prominent when unchangeable or natural factors like gender and lifetime effected variables such as education are disregarded. And the theory does not imply that it should be the prominent factor but should have a positive relationship to imply the decision is under credit barriers regardless of the strength of the relationship. Therefore, it is clear that all the choice probabilities are positively significant with the wealth covariate.

In terms of the other covariates in the estimated model, the results are almost identical in the direction across the different groups except trained. Being a person whose parents self-employed or having training has a strong positive effect on entering as entrepreneur while it cannot predict entrepreneurial choice probability of the self-employment group. Education level has a strong positive effect on both. An increase in one unit of the education variable increases the odds of being an entrepreneurs group by about two times while it impacts by less than one half times for the self-employed choice. Further, education is the most confounded for the entrepreneurs, but it takes the last for the other compared to subsistence group when Wald value is considered. As many other studies have found, being a male has a significant positive relationship with the choice probability for both. It is a one of the prominent factors in predicting entrepreneurship, having odds ratio of 3.9. Males are almost four times more likely to be in the entrepreneur group than females. Labor force experience has a positive, but decreasing effect on starting a business, while working in the state or private sector as a salaried employee previously significantly predict the probability of starting as in the self-employed group. The positive and significant effect of the previous salaried employment indicates that some households are "pushed" into self-employed may be due to a need of supportive income even after getting retired to cover the cost of living. Not surprisingly, people who are unemployed more likely to being in the sector regardless of the group. However, this relation is negligible for the entrepreneurs. Unemployed persons are more likely to start self-employments showing significance at the 5 percent level of significance with odds of 2.1. Results for the variable measuring the person's attitude toward risk show a strong positive relationship between being willing to take higher risks and starting a business as an entrepreneur. Literature on inheritances on the decision into entrepreneurship is positive and significant for developing countries and also small and medium enterprise sector (Blanchflower \& Oswald, 1998; Holtz-Eakin et al., 1994). This variable has no predictive power in informal sector micro entrepreneurship in the country. However, the data received is less reliable which are from the recall memory of informal sector micro entrepreneurs and defining their receipts is even difficult. Therefore, the reported results could be further investigated. Some of the demographic factors such as age, marital status, gender which are important in some studies (Blanchflower, 2000; Delmar \& Davidsson, 2000; Minniti et al., 2005; Mueller, 2006) do not affect the probability of entrepreneurial choice in the current study.

Regression results of the logit models with linear specification of wealth predict a positive and significant relationship. Then it is worth investigating this relationship with the non-linear specification of the variable. In order to do this quartiles of the distribution of wealth is taken into account constructing three dummy variables to represent the first, second and third quarters. And additionally two dummies were created to represent secondary and above-secondary education levels taking primary or below as the reference group.

It is quite interesting and carefully understood the minus coefficient reported in Table 2 for the secondary educator which does not imply negative impact of education. This shows low educator's preference is higher for to be self-employed than the secondary educators. Table 2 further presents the results of two logit models for non-linear wealth specification, where the dependent variable is choice events as mentioned above. As it was 
reported, all parts of the wealth distribution show a positive and significant effect across two models. This implies that the probability of the transition into a business increases gradually as one move from self-employment to entrepreneur group.

Table 2. Choice probability of entrepreneurial engagement: multinomial logit estimates for wealth levels

\begin{tabular}{|c|c|c|c|c|c|c|}
\hline \multirow{2}{*}{$\begin{array}{l}\text { Variables } \\
\end{array}$} & \multicolumn{3}{|c|}{ Self Employed } & \multicolumn{3}{|c|}{ Entrepreneur } \\
\hline & $\mathrm{B}$ & Wald & Odds R & $\mathrm{B}$ & Wald & Odds R \\
\hline \multirow[t]{2}{*}{ Age } & -0.532 & 3.573 & 0.531 & -1.319 & 7.652 & 0.267 \\
\hline & $(0.434)$ & & & $(0.477)$ & & \\
\hline \multirow[t]{2}{*}{ Gender $(\mathrm{F})$} & 0.005 & 0.139 & 1.004 & $0.022 *$ & 0.759 & 1.012 \\
\hline & $(0.031)$ & & & $(0.013)$ & & \\
\hline \multirow[t]{2}{*}{ Above Secondary } & $0.714^{*}$ & 3.344 & 2.042 & $1.512 * * *$ & 11.519 & 4.535 \\
\hline & $(0.390)$ & & & $(0.445)$ & & \\
\hline \multirow[t]{2}{*}{ Secondary } & $-0.400 *$ & 1.408 & 0.741 & $0.594 * *$ & 2.234 & 1.812 \\
\hline & $(0.334)$ & & & $(0.398)$ & & \\
\hline \multirow[t]{2}{*}{ Unemployed } & $0.599 * *$ & 0.808 & 1.820 & $0.358^{*}$ & 0.571 & 1.294 \\
\hline & $(0.305)$ & & & $(0.341)$ & & \\
\hline \multirow[t]{2}{*}{ Non risk taker } & 0.610 & 4.339 & 1.240 & $0.351 *$ & 1.467 & 1.286 \\
\hline & $(0.693)$ & & & $(-0.334)$ & & \\
\hline \multirow[t]{2}{*}{ Initial wealth $\mathrm{T} 2$} & $0.497 *$ & 2.226 & 1.644 & $0.938 * *$ & 6.261 & 2.555 \\
\hline & $(0.333)$ & & & $(0.375)$ & & \\
\hline \multirow[t]{2}{*}{ Initial wealth $\mathrm{T} 3$} & $0.434^{*}$ & 1.268 & 1.544 & $0.551 * *$ & 1.774 & 1.734 \\
\hline & $(0.386)$ & & & $(0.454)$ & & \\
\hline \multirow[t]{2}{*}{ Parents occu/Tradition } & 0.112 & 0.135 & 1.118 & 0.678 & 3.949 & 1.970 \\
\hline & $(0.304)$ & & & $(0.341)$ & & \\
\hline \multirow[t]{2}{*}{ Inherent } & 0.114 & 0.123 & 1.121 & -0.245 & 0.403 & 0.783 \\
\hline & $(0.326)$ & & & $(0.386)$ & & \\
\hline
\end{tabular}

$* * * \mathrm{p}<0.001 ; * * \mathrm{p}<0.01 ; * \mathrm{p}<0.05,(\mathrm{SE})$

Although similar relationship result is found for all wealth dummies, the magnitude of the effect is somewhat different across the groups compared to the lowest quartile. Persons who are in the first quartile are more likely to start as a self-employer while wealthy assets owners more likely to begin at the entrepreneur level (De Mel et al., 2008; Evans Jevonic, 1989). The relationship between wealth and entrepreneurship appears to be driven by these high-wealth households as well.

The results reported for the other variables do not seem to deviate due to the quartile representation of the wealth measure in the model. Findings of the estimated model lend much support for the implication of the positive relationship between wealth and starting a business which provide evidence of the existence of liquidity constraints. Further, it shows that liquidity constraints certainly exist and more strong for low wealth persons than wealthy persons.

In constructing a suitable ex-ante total wealth proxy for the sensitivity analysis, this study used the asset index approach which is increasingly advocated by the scholars (Moser \& Felton, 2007). The values of this aggregate index are created by using principal component analysis of 14 consumer durables from the household belongings and two dummy variables (have $=1$, have not $=0$ ) which were acquired prior to the beginning of the microenterprise, reported in the questionnaires. Therefore the problem of endogeneity is controlled from the wealth proxy. 
Table 3. Choice probability of entrepreneurial engagement: Multinomial logit estimates for wealth proxy

\begin{tabular}{|c|c|c|c|c|c|c|}
\hline \multirow{2}{*}{ Variables } & \multicolumn{3}{|c|}{ Self Employed } & \multicolumn{3}{|c|}{ Entrepreneur } \\
\hline & B & Wald & Odds R & B & Wald & Odds R \\
\hline \multirow[t]{2}{*}{ Education level } & $0.190 * *$ & 0.349 & 1.094 & $0.349 * *$ & 3.693 & 1.417 \\
\hline & $(0.152)$ & & & $(0.181)$ & & \\
\hline \multirow[t]{2}{*}{ Non risk taker } & -0.208 & 1.001 & 0.812 & $-0.372 *$ & 1.487 & 0.931 \\
\hline & $(0.208)$ & & & $(0.244)$ & & \\
\hline \multirow[t]{2}{*}{ Inherent } & 0.069 & 0.049 & 1.071 & 0.404 & 1.154 & 1.498 \\
\hline & $(0.311)$ & & & $(0.376)$ & & \\
\hline \multirow[t]{2}{*}{ Unemployed } & $0.634 * *$ & 4.473 & 1.886 & $0.281 *$ & 0.286 & 1.324 \\
\hline & $(0.300)$ & & & $(0.339)$ & & \\
\hline \multirow[t]{2}{*}{ Parents occu/Tradition } & -0.088 & 0.089 & 0.916 & 0.466 & 1.947 & 1.594 \\
\hline & $(0.293)$ & & & $(0.334)$ & & \\
\hline \multirow[t]{2}{*}{ Initial wealth } & $0.296^{*}$ & 2.538 & 1.344 & $0.684 * * *$ & 10.708 & 1.982 \\
\hline & $(0.186)$ & & & $(0.209)$ & & \\
\hline
\end{tabular}

*** $\mathrm{p}<0.001 ; * * \mathrm{p}<0.01 ; * \mathrm{p}<0.05,(\mathrm{SE})$

The characteristics that cause persons to build up higher values asset index could be the characteristics that lead households into entrepreneurship. More advantageously the representative asset measure could be capturing the effects of unobservable wealth variables that are correlated with wealth and the desire the starting point of a business (Moser \& Felton, 2007).

According to the Multinomial logistic results reported in Table 3, asset index and the choice of entrepreneurship related positively and significantly by proving the results reported earlier. Wealth proxy represents a strong relation for the self-employed compared to subsistence while showing the unit increase cause odds to be increased by almost 1.1. For the entrepreneur group this variable influence more strongly (1.4). Wealthy persons in terms of index values are more likely to be in the entrepreneur group rather than in the subsistence or self-employed. As noted in Table 3, other covariates show similar direction in relation to choice probability regardless with the wealth measure used. However, the effects show some deviations in terms of the size. Two models confirmed the positive relationship of wealth and entrepreneurial choice for urban informal sector micro entrepreneurs in the country showing the existence of liquidity constraints.

\section{Conclusion}

In sum, the implication of the theoretical model tested in the study is that if there is no correlation between skills and wealth, then the choice probability of starting point of the business is positive with wealth when financial constraints are exists. This positive correlation between wealth and the probability of starting a business would imply that initial wealth determines the amount of capital required for business startups thus providing evidence of financial constraints.

The estimate of the coefficient on wealth shows that household initial wealth has a positive effect on the probability of starting choice of a business and is statistically significant at conventional levels for the whole sample. It was found that the entrepreneurs are credit constrained at their entry and survival as well. More crucially, lack of credit access has found to be the most binding constraints to the potential entrepreneur groups so that they are unable to utilize the economic opportunities available in the local area in a sustainable and successful manner. This means that if households or micro enterprise holders are wealthy enough they can go beyond the subsistence level which ultimately contributes the growth purposes of the country as a whole. Estimated regression coefficients on wealth, wealth quartiles and wealth proxy show almost similar results confirming positive significant over the entrepreneurial choice probability. The results further suggest that wealth and education are the main factors that strongly influence on the probability of becoming a micro entrepreneur at any form. The results also show positive effects of tradition, trained or parent's occupation and previous employment on the probability of starting a business as a self-employed or entrepreneur compared to subsistence. It also appears that women are less likely to become entrepreneurs compared to men in all the groups of interest. 


\section{Implications}

The findings of this study have some implications for theory, and practice for increasing and improving entrepreneurship, particularly in the urban informal sector in Sri Lanka. From the theoretical point of view, the current study will be a guide to investigate the micro entrepreneurship specifically in the developing world in a more sophisticated manner before commencing ad-hoc policies on miss-specified targets. Further, this study will open new avenues to future research endeavors on urban poverty and micro entrepreneurship in Sri Lanka.

Some of the policy implications drawn from the study are strengthening of the retail lending techniques to lower transaction costs in dealing with entrepreneurs in micro business, forming policies to develop skills and change attitudes complementary to enhance credit facilities, provision of promotion-based, and community friendly, entrepreneur-centered, follow-up training to upgrade their knowledge and management of enterprising skill. The findings of this study further imply the need of supportive services to reduce household burdens on the women entrepreneurs in order to make them more productive rather than trying to assist them for a supportive income.

\section{References}

Arunatilake, N., \& Jayawardena, P. (2005). Informality in the Sri Lankan labour market. Colombo: Institute of Policy Studies.

Blanchflower, D. G. (2000). Self-employment in OECD countries. Labour Economics, 7(5), 471-505. http://dx.doi.org/10.1016/S0927-5371(00)00011-7

Blanchflower, D. G., \& Meyer, B. (1994). A longitudinal analysis of the young self-employed in Australia and the United States . Small Business Economics 6, 1-20. http://dx.doi.org/10.1007/BF01066108

Blanchflower, D. G., \& Oswald, A. (1998). What makes an entrepreneur? Journal of Labor Economics, 16, 29-60. http://dx.doi.org/10.1086/209881

Bonte, W., Falck, O., \& Heblich, S. (2009). The impact of regional age structure on entrepreneurship. Economic Geography 85(3), 269-287. http://dx.doi.org/10.1111/j.1944-8287.2009.01032.x

Burke, A. E., FitzRoy, F. R., \& Nolan, M. A. (2000). When less is more: Distinguishing between entrepreneurial choice and performance. Oxford Bulletin of Economics and Statistics, 62(5), 565-587. http://dx.doi.org/ 10.1111/1468-0084.00190

Cressy, R. (2000). Credit rationing or entrepreneurial risk aversion? An alternative explanation for the Evans and Jovanovic finding. Economics Letters, 66, 235-240. http://dx.doi.org/10.1016/S0165-1765(99)00216-5

Cunningham, W., \& Maloney, W. F. (2001). Heterogeneity among Mexicos microenterprises: An application of factor and cluster analysis. Economic Development and Cultural Change, 5, 131-156. http://dx.doi.org/10.1086/340012

Daniels, L. (1999). The role of small enterprises in the household and national economy in Kenya: A significant contribution or a last resort? World Development, 27(1), 55-65. http://dx.doi.org/10.1016/S0305-750 $\mathrm{X}(98) 00120-\mathrm{X}$

De Mel, S. M., \& Woodruff, C. (2010). Wage subsidies for microenterprises. American Economic Review: Papers \& Proceedings, 100, 614-618.

De Mel, S., McKenzie, D., \& Woodruff, C. (2008). Returns to capital in microenterprises: Evidence from a field experiment. The Quarterly Journal of Economics, 123(4), 1329-1372. http://dx.doi.org/10.1162/qjec.2008. 123.4.1329

Delmar, F., \& Davidsson, P. (2000). Where do they come from? Prevalence and characteristics of nascent entrepreneurs. Entrepreneurship and Regional Development, 12(1), 1-23. http://dx.doi.org/10.1080/0898 56200283063

Desai, S. (2010). Entrepreneurship in Iraq: Understanding the constraints. Retrieved from UNU- World Institute for Development Economic Reseach: http://www.wider.unu.edu/publications/newsletter/articles/en_GB/ Entrepreneurship-article-1109/

Dunn, T., \& Holtz-Eakin, D. (1996). Financial capital, human capital, and the transition to self-employment: Evidence from intergenerational links. NBER Working paper 5622. Retrieved from http://EconPapers.repec. org/RePEc:nbr:nberwo:5622

Ebert, H. (1999). Improvement to urban infrstructure and service delivery in underserved settlements in Colombo. Colombo: German technical cooperation. 
Evans, D. S., \& Leighton, L. S. (1989). Some empirical aspects of entrepreneurship. American Economic Review , 79(3), 519-535.

Evans, D., \& Jovanovic, B. (1989). An etimated model of entrepreneurial choice under liquidity constraints. Journal of Political Economy, 97, 808-827. Retrieved from http://www.jstor.org/stable/1832192

Fairoz, F., Hirobumi, T., \& Tanaka, y. (2010). Entrepreneurial Orientation and Business Performance of Small and Medium Scale Enterprises of Hambantota District Sri Lanka. Asian Social Science, 6(3), 34-46.

FIELD. (2012). US Microenterprise Census Highlights. The Aspen Institute, Washington, D.C. Retrieved from http://fieldus.org/Publications/FY2010CensusHighlightsNEW.pdf

Fields, G. S. (1990). Labor market modeling and the urban informal sector: Theory and evidence in the informal sector revisited (ed. David Tumham, Bernard Salome, and Antoine Schwartz ed.). Paris: OECD.

Gentry, W. M., \& Hubbard, R. G. (2000). Entrepreneurship and household saving. Mimeograph, Columbia University.

Grosh, B., \& Somolekae, G. (1996). Mighty oaks from little acorns: Can microenterprise serve as the seedbed of industrialization? World Development 24, 1879-1890. http://dx.doi.org/10.1016/S0305-750X(96)00082-4

Gunatilaka, R. (2008). Informal employment in Sri Lanka: Nature, probability of employment, and determinants of wages. New Delhi: International Labour Organization, subregional office for South Asia.

Hettige, S. T. (1989). Urban informal economy, the politico - economic process and the haring of urban space: Recent trends with particular reference to Colombo. Upanathi, 4(1\&2), 74.

Holtz-Eakin, D., Joulfaian, D., \& Rosen, H. S. (1994a). Entrepreneurial decisions and liquiduity constraints. RAND Journal of Economics, 23, 333-347. http://dx.doi.org/10.3386/w4526

Holtz-Eakin, D., Joulfaian, D., \& Rosen, H. S. (1994b). Sticking it Out: Entrepreneurial Survival and Liquidity Constraints. Journal of Political Economy, 102, 53-75. Retrieved from http://www.jstor.org/stable/2138793

Hurst, E., \& Lusardi, A. (2004). Liquidity constraints, household wealth and entrepreneurship. Journal of Political Economy, 112(2), 319-347. Retrieved from http://www.jstor.org/stable/10.1086/381478

Jovanovic, B. (1982). Selection and evolution of industry. Econometrica, 50, 649-670.

Kaufman, A. S., \& Horn, L. J. (1996). Age changes on tests of fluid and crystallized ability for women and men on the Kaufman Adolescent and Adult Intelligence Test. Archives of Clinical Neuropsychology, 4, 97-121. http://dx.doi.org/10.1016/0887-6177(95)00003-8

Knight, F. H. (1971). Risk, uncertainty and profit (G.J. Stigler ed.). University of Chicago Press: Chicago.

Kuzilwa, J. A. (2005). The role of credit for small business success of the national entrepreneurship development fund in: A study Tanzania. Journal of Entrepreneurship, 14(2). http://dx.doi.org/10.1177/0971355705014 00204

Lazear, E. P. (2002). Entrepreneurship. NBER Working Paper 9109, National Bureau of Economic Research.

Lel, U., \& Udell, G. (2002). Financial constraints, start-up firms and personal commitments. Mimeo, Kelly School of Business, Indiana University.

Levy, B. (1991). Obstacles to developing small and medium-sized enterprises: An empirical assesment. Worla Bank working paper No 588.

Levy, B., \& Bradburd, R. (1995). Zimbabwe's new entrepreneur : An emerging success story ? In W. Bank, Microeconomics 1. Washington D C.

Lindh, T., \& Ohlsson, H. (1996). Self-employment and windfall gains: Evidence from the Swedish lottery. The Economic Journal, 106, 1515-1526. Retrieved from http://EconPapers.repec.org/RePEc:ecj:econjl:v:106:y: 1996:i:439:p:1515-26

Lucas, J. R. (1978). On the size distribution of business. Bell Journal of Economics, 9, 508-523. Retrieved from http://www.jstor.org/stable/3003596

Magri, S. (2011). Household wealth and entrepreneurship: Is there a link? SSRN Working Paper Series.

Mead, D. C., \& Liedholm, C. (1998). The dynamics of micro and small enterprises in developing countries. World Development 26(1), 61-74. http://dx.doi.org/10.1016/S0305-750X(97)10010-9

Minniti, M., Arenius, P., \& Langowitz, N. (2005). GEM 2004 report on women and entrepreneurship. Centre for 
Women's Leadership at Babson College, London Business school.

Mondragon-Velez, C. (2010). The transition to entrepreneurship: Human capital, wealth and the role of liquidity constraints. SSRN Working Paper Series.

Moser, C., \& Felton, A. (2007). Intergenerational asset accumulation and poverty reduction in Guayaquil, Ecuador. CPRC Working paper, 87.

Mullei, A. (2002). Growth and transformation of small manufacturing firms in Africa. Nirobi: African center for economic growth.

Nanayakkara, A. G. (2006). Poverty in Sri Lanka. Colombo: DCS.

Naudé, W. (2010). Entrepreneurship, developing countries, and development economics: new approaches and insights. Small Business Economics 34(1), 1-12. Retrieved from http://www.jstor.org/stable/40540452

Pisani, M. J., \& Patrick, J. M. (2002). A conceptual model and propositions for bolstering entrepreneurship in the informal sector: The case of Central America. Journal of Developmental Entrepreneurship, 7(1), 95-111.

Quadrini, V. (1999). The importance of entrepreneurship for wealth concentration and mobility. Review of Income and Wealth, 45, 1-19.http://dx.doi.org/10.1111/j.1475-4991.1999.tb00309.x

Reynolds, P. D., Hay, M., \& Camp, S. M. (2002). Global entrepreneurship monitor, 2002 executive report. Babson College, London Business School and Kauffman Foundation.

Roy, M.-A., \& Wheeler, D. (2006). A survey of micro-enterprise in urban West Africa: drivers shaping the sector. Development in Practice, 16(5), 452-464. http://dx.doi.org/10.1080/09614520600792432

RUSP. (2009). Realocation of underserved settlements: Presentation. Colombo: Ministry of defence and urban development.

Ryan, J. J., Sattler, J. M., \& Lopez, S. J. (2000). Age effects on Wechsler Adult Intelligence Scale-III Subsets. Archives of Clinical Neuropsychology, 15, 311-317.

Sevanatha. (n. d.). Urban slums reports: The case of Colombo, Sri Lanka. Colombo: Urban resources centre.

Shaw, J. (2004). Microenterprise occupation and poverty reduction inmicrofinance programs: Evidence from Sri Lanka. World Development, 32(7), 1247-1264. http://dx.doi.org/10.1016/j.worlddev.2004.01.009

Sumanasena, K. (2005). Country paper-Sri Lanka. Colombo: Sri Lanka Chamber of Small Industries.

World Bank. (2002). Urban transport strategy review: Cities on the move. Washington DC: World Bank.

World Bank. (2013). World development report. Wachinto D C: World Bank.

\section{Copyrights}

Copyright for this article is retained by the author (s), with first publication rights granted to the journal.

This is an open-access article distributed under the terms and conditions of the Creative Commons Attribution license (http://creativecommons.org/licenses/by/3.0/). 